\title{
Molecular Mechanisms of Chronic Wasting Disease Prion Propagation
}

\author{
Julie A. Moreno and Glenn C. Telling \\ Prion Research Center (PRC) and the Department of Microbiology, Immunology, and Pathology, \\ Colorado State University, Fort Collins, Colorado 80525 \\ Correspondence: glenn.telling@colostate.edu
}

Prion disease epidemics, which have been unpredictable recurrences, are of significant concern for animal and human health. Examples include kuru, once the leading cause of death among the Fore people in Papua New Guinea and caused by mortuary feasting; bovine spongiform encephalopathy (BSE) and its subsequent transmission to humans in the form of variant Creutzfeldt-Jakob disease (vCJD), and repeated examples of large-scale prion disease epidemics in animals caused by contaminated vaccines. The etiology of chronic wasting disease (CWD), a relatively new and burgeoning prion epidemic in deer, elk, and moose (members of the cervid family), is more enigmatic. The disease was first described in captive and later in wild mule deer and subsequently in free-ranging as well as captive Rocky Mountain elk, white-tailed deer, and most recently moose. It is therefore the only recognized prion disorder of both wild and captive animals. In addition to its expanding range of hosts, CWD continues to spread to new geographical areas, including recent cases in Norway. The unparalleled efficiency of the contagious transmission of the disease combined with high densities of deer in certain areas of North America complicates strategies for controlling CWD and raises concerns about its potential spread to new species. Because there is a high prevalence of CWD in deer and elk, which are commonly hunted and consumed by humans, the possibility of zoonotic transmission is particularly concerning. Here, we review the current status of naturally occurring CWD and describe advances in our understanding of its molecular pathogenesis, as shown by studies of CWD prions in novel in vivo and in vitro systems.

\section{EPIDEMIOLOGY AND HOST RANGE}

Chronic wasting disease (CWD) was first identified in the late 1960s as a fatal wasting syndrome of mule deer (Odocoileus hemionus hemionus) and black-tailed deer (Odocoileus hemionus columbianus) held in captivity in several wildlife facilities in northern Colorado. By the late 1970s, CWD was histopathologically recognized as a prion disease by the late
Elizabeth Williams (Williams and Young 1980, 1992). A retrospective study also revealed CWD infection of mule and black-tailed deer that resided at the Toronto Zoo between 1973 and 2003 (Dube et al. 2006). The disease was also identified in mule deer in a research facility in Wyoming and in captive wapiti, or Rocky Mountain elk (Cervus elaphus nelsoni), in both the Colorado and Wyoming wildlife facilities. Thereafter, CWD was described in free-ranging

Editor: Stanley B. Prusiner

Additional Perspectives on Prion Diseases available at www.perspectivesinmedicine.org

Copyright (C) 2018 Cold Spring Harbor Laboratory Press; all rights reserved; doi: 10.1101/cshperspect.a024448

Cite this article as Cold Spring Harb Perspect Med 2018;8:a024448 
mule deer and elk in southeastern Wyoming and northeastern Colorado (Williams and Young 1980, 1982, 1992) and was described in white-tailed deer in Nebraska and South Dakota in 2001 (Williams 2005). Surveillance and modeling studies indicated that CWD occurred endemically among free-ranging deer and elk in a contiguous area encompassing northeastern Colorado, southeastern Wyoming, and western Nebraska, and that CWD was most likely present in free-ranging cervids in this "endemic region" several decades before its detection (Miller et al. 2000). Long thought to be limited to this endemic region, a new area was identified in Saskatchewan, Canada (Williams and Miller 2002), in 1996, and CWD also emerged in freeranging populations of white-tailed deer (Odocoileus virginianus) in southern Wisconsin (Joly et al. 2003) in 2002. Most recently, CWD was present in a wild moose (Alces alces shirasi) killed by a hunter in Colorado (Baeten et al. 2007) and in captive moose in Wyoming (Kreeger et al. 2006). The disease was subsequently found in additional free-ranging moose in Colorado and Wyoming and most recently in Alberta, Canada.

The spread of CWD in North America appears to be irrevocable. At the time of this review, CWD has been found in both wild and farm-raised cervids from 22 North American states, two Canadian provinces, and in Norway. Identification of CWD-infected animals in areas previously thought to be free of infection may be partly related to increased surveillance and spread of the disease by natural migration and by humans who transport infected cervids to other locations. These factors almost certainly play a role in the emergence of CWD in new areas. Moreover, this appears to be how outbreaks of the disease occurred in elk in the Republic of Korea in 2001, 2004, and 2005as a result of the country's importation of subclinically infected animals (Sohn et al. 2002; Kim et al. 2005). In 2010, additional CWD cases were observed in red deer (Cervus elaphus), sika deer (Cervus nippon), and crossbred sika and red deer (Lee et al. 2013).

In April 2016, CWD was detected for the first time in Euorpe and for the first time in free-ranging reindeer (Rangifer tarandus tarandus) (Benestad et al. 2016). Western blot analysis of brain material from this Norwegian animal, which was from the Selbu region of SørTrøndelag county (Norway), showed that $\operatorname{PrP}^{\mathrm{Sc}}$ (the pathogenic form of the normal cellular protein) glycosylation and molecular weight profiles were similar to $\mathrm{PrP}^{\mathrm{Sc}}$ from North American elk with CWD. It was also found that $\operatorname{PrP}^{\mathrm{Sc}}$ deposition patterns were concordant with those of $\mathrm{PrP}^{\mathrm{Sc}}$ in diseased reindeer orally inoculated with North American CWD (Mitchell et al. 2012). In subsequent months, CWD was diagnosed in a second reindeer from the Selbu region, as well as in two moose from the Nordfjella region in southern Norway, which is separated from Sør-Trøndelag by several hundred kilometers (S Benestad, pers. comm.). The origin of these new European cases is currently unclear.

\section{PATHOGENESIS}

Clinical signs of infected deer and elk can be subtle, which makes diagnosis difficult, and include weight loss, behavioral alterations, apparent ruminal atony, and salivary defluxion in later stages of the disease. Clinical features include gradual loss of body condition, resulting in emaciation (hence the term "wasting disease"), and behavioral changes that include generalized depression and loss of fear of humans (Williams 2003). At later stages, infected animals may display polydipsia and polyuria, sialorrhea, and generalized incoordination. The clinical course in captive animals is slowly progressive, and after diagnosis, most animals survive for a few weeks up to 3 to 4 mo.

Within a short time after an animal ingests material contaminated with CWD prions, the pathogenic prions migrate to lymphoid centers associated with the alimentary tract, including the tonsil and retropharyngeal lymph nodes (Sigurdson et al. 2002). Following neuroinvasion, CWD prions travel throughout the central nervous system (CNS) via the ascending fibers of the autonomic nervous system, culminating in prion deposits and spongiform degeneration in the dorsal motor nucleus of the vagus nerve in the obex region of the medulla oblongata. 
Ultimately, prions replicate throughout the CNS. Like other prion diseases, postmortem pathognomonic lesions are confined to the CNS and consist of intraneuronal vacuolation, neuropil spongiosis, astrocytic hypertrophy, and hyperplasia (Williams and Young 1993). CWD is characterized by extensive deposition of $\mathrm{PrP}^{\mathrm{Sc}}$ prions in the CNS and lymphoid tissue, the latter being detectable in the early stages of the disease (Sigurdson et al. 1999; Fox et al. 2006). The pathogenesis of CWD seems to vary between deer and elk, with fewer deposits seen in the lymphoid tissue of elk compared with deer (Race et al. 2007). Florid amyloid plaques also feature in the neuropathology of diseased deer (Liberski et al. 2001). Other tissues in which $\mathrm{PrP}^{\mathrm{Sc}}$ or infectivity has been detected in deer and elk include the pancreas (Sigurdson et al. 2001; Fox et al. 2006), adrenal gland (Sigurdson et al. 2001; Fox et al. 2006), and cardiac muscle (Jewell et al. 2006). CWD prions have also been detected in saliva and blood by bioassay (Mathiason et al. 2006) and in urine by protein-misfolding cyclic amplification (PMCA) (Haley et al. 2009a) and bioassay (Haley et al. 2009b), which suggests that these body fluids play a role in the transmission and dissemination of the disease. The fecal material of subclinical deer also harbors infectivity (Haley et al. 2009b; Tamgüney et al. 2009). Please see Haley and Hoover (2015), who have recently reviewed pathogenesis in the natural host, for an exhaustive description of the clinical and pathological features of the disease.

\section{NATURAL TRANSMISSION}

The maximum incubation period of CWD in naturally infected animals is unknown, but most natural cases occur in animals 3 to $7 \mathrm{yr}$ old, with the majority of animals probably developing the disease within $3 \mathrm{yr}$ of infection (Miller et al. 1998). Although CWD has been shown to be experimentally transmissible after intracerebral inoculation of mule deer with incubation periods up to $2 \mathrm{yr}$ (Williams and Young 1992), limited transmission studies have indicated that CWD developed $~ 25 \%$ more rapidly in orally challenged elk than deer
(16 mo for mule deer and 12 mo for elk) (Williams 2003). Levels of $\operatorname{PrP}^{\mathrm{Sc}}$ were found to be higher in the tonsil and retropharyngeal lymph nodes of CWD-infected deer than elk (Race et al. 2007). Because this finding correlates with the natural prevalence of CWD in these species, Race et al. speculated that CWD-infected deer may be more likely than elk to transmit the disease.

In the wild, the highly efficient transmission of CWD appears unparalleled among prion diseases (Williams and Young 1980; Miller et al. 2000; Miller and Williams 2003). The remarkably contagious nature of CWD has been documented in a captive mule deer population, wherein $90 \%$ of the mule deer present in the population for $>2 \mathrm{yr}$ ultimately developed the disease (Williams and Young 1980). Although the natural route of transmission is not precisely known, lateral transmission (Williams and Miller 2002) by ingesting forage or water contaminated by secretions, excretions, or other sources (for example, CWD-infected carcasses) (Miller et al. 2004) has long been thought to be the most plausible natural route. The presence of CWD prions in saliva, blood, urine, and feces (Haley et al. 2009a,b, 2011; Mathiason et al. 2006; Tamgüney et al. 2009) is consistent with this mechanism of contagious lateral transmission. Using transgenic ( $\mathrm{Tg}$ ) mice bioassays, CWD prions were detected in elk antler velvet, and the annual shedding of this material increases the possibility that it may also play a role in transmitting the disease (Angers et al. 2009). Recently developed highly sensitive methods for CWD detection based on a standardized real-time quaking-induced conversion (RT-QuIC) assay are likely to greatly facilitate epidemiological studies (Haley et al. 2014; Henderson et al. 2015).

Pertinent to the issue of disease transmission is the seemingly indefinite persistence of CWD in the environment (Miller et al. 2004; Seidel et al. 2007), a feature that is linked to the unusual and extreme resistance of prions to degradation. Coupled with this characteristic, prions bind avidly to soil particles, particularly montmorillonite clay and quartz (Smith et al. 2011), and remain infectious after oral consumption (Johnson et al. 2006a, 2007; 
Saunders et al. 2012). This binding requires the flexible $\mathrm{N}$ terminus of $\mathrm{PrP}^{\mathrm{Sc}}$ and cleavage with proteinase Keffectively releases prions from soil particles (Saunders et al. 2011). Of note, there appears to be a close correlation between these soil types and CWD prevalence (Saunders et al. 2012).

Shedding of CWD prions during infection raised the possibility that contamination of plant materials may feature in disease transmission. To address this, Pritzkow and colleagues (2015) analyzed the binding and retention of $\mathrm{PrP}^{\mathrm{Sc}}$ to plants. Their study found that even small quantities of prions in diluted brain homogenate or in urine and feces bind to wheat grass roots and leaves for several weeks, and that animals are efficiently infected by ingesting prion-contaminated plants. These features apply to prions from diverse origins, including from CWD. Moreover, root uptake of prions from contaminated soil is followed by their transport to the stem and leaves.

\section{IMPACT AND MANAGEMENT OF CWD}

Although most U.S. states and Canadian provinces have introduced CWD surveillance programs, the extent of these programs is variable, ranging from targeted surveillance in some states to mandatory testing of all animals suspected of dying of CWD in others. Complicating the issue, diagnosis can only be unequivocally made following postmortem analysis of CNS materials, and current evaluations almost certainly underestimate the true prevalence of the disease. Although testing for CWD in other countries has been minimal, limited active surveillance has, to date, not detected CWD in European countries other than Norway or Japan (Roels et al. 2004; Kataoka et al. 2005; Schettler et al. 2006).

The prevalence of CWD can be as high as $30 \%$ in some areas of Colorado (Williams 2005), and wildlife management efforts to contain or eradicate CWD in the state have proven unsuccessful (Conner et al. 2007). Based on hunter-harvested animal surveillance, the prevalence of CWD in the endemic area from 1996 to 1999 was estimated at $~ 5 \%$ in mule deer, $~ 2 \%$ in white-tailed deer, and $<1 \%$ in elk (Spraker et al. 1997). Several studies have attempted to address the impact of CWD on cervid populations. Experimental studies show that CWD lowers deer survival and can depress population growth rates when prevalence becomes sufficiently high (Miller et al. 2008; Dulberger et al. 2010). Modeling approaches have provided conflicting predictions of the consequences of CWD on infected populations (Wasserberg et al. 2009; Almberg et al. 2011; Geremia et al. 2015).

CWD has both a significant economic impact and influences wildlife conservation. The U.S. Fish and Wildlife Service estimated that a total of $\$ 33.7$ billion was spent on hunting items in 2011, and an estimated 11.6 million hunters pursued big game such as deer and elk (U.S. Census Bureau 2011). Within the first month of diagnosing CWD in free-ranging deer in 2002, Wisconsin's wildlife management agency spent $\sim \$ 250,000$ in control and public information efforts and subsequently upward of $\$ 2.5$ million a year for additional CWD control efforts (Telling 2013). Saskatchewan has spent $\sim \$ 30$ million to eradicate the disease within infected commercially operated game farms (Oklahoma Department of Wildlife Conservation 2002).

\section{EXPERIMENTAL TRANSMISSION OF CWD}

Other cervid species are susceptible to CWD following experimental challenge. These include European red deer (Cervus elaphus elaphus) (Martin et al. 2009) and muntjac deer (Muntiacus reevesi) (Nalls et al. 2013). Brain tissue from CWD-infected white-tailed deer and elk produced disease in only four of 13 intracerebrally inoculated fallow deer (Dama dama) (Hamir et al. 2008), and the same species appeared resistant when cohoused in paddocks with CWD-infected mule deer (Rhyan et al. 2011), suggesting relative resistance of this cervid species to CWD.

Whether the natural host range of CWD extends beyond the family Cervidae is currently unclear. However, the remarkably high rate of CWD prion transmission brings into question the risk posed to livestock of developing a novel CWD-related prion disease via shared grazing of CWD-contaminated rangeland. This issue 
has been addressed by transmitting CWD to cattle (Hamir et al. 2001, 2005, 2006a, 2007a) and sheep (Hamir et al. 2006b). In the case of cattle, $\mathrm{PrP}^{\mathrm{Sc}}$ was detected in $\sim 40 \%$ of intracerebrally inoculated animals. Low rates of disease also occurred in intracerebrally inoculated sheep. Host genotype appeared to affect the efficiency of transmission. Tg mice expressing ovine or bovine prion protein $(\mathrm{PrP})$ have also been challenged with CWD, thus far with negative outcomes (Tamgüney et al. 2006). Davenport et al. (2015) used the RT-QuIC assay to compare the conversion properties of CWD and bovine spongiform encephalopathy (BSE) prions, as well as feline-adapted versions of these prions. CWD, BSE, and feline-adapted CWD prions most effectively seeded cervid, bovine, and feline bacterially expressed recombinant $\mathrm{PrP}$ $(\mathrm{rPrP})$, respectively, whereas feline spongiform encephalopathy (FSE) prions more efficiently converted bovine than feline rPrP. To determine the potential of these prions to convert human PrP, human $\mathrm{rPrP}$ was used as a substrate in RT-QuIC. Remarkably, CWD, feline-adapted CWD, BSE, and FSE prions all converted human rPrP, although not as efficiently as sporadic Creutzfeldt-Jakob disease (CJD) prions.

Experimental transmission to other species has shown mixed results. Studies by the late Dr. Richard Marsh in the mid-1980s at the University of Wisconsin showed that the CWD agent transmitted poorly to Syrian golden hamsters, ferrets, and mink (Bartz et al. 1998; Marsh et al. 2005; Sigurdson et al. 2008). Other susceptible species include several species of voles, whitefooted mice, deer mice, cats, raccoons, and squirrel monkeys (Hamir et al. 2003, 2007b; Race et al. 2009a, 2014; Heisey et al. 2010; Di Bari et al. 2013; Mathiason et al. 2013; Seelig et al. 2015). Although non-Tg mice have been reported to be resistant to CWD infection (Browning et al. 2004), limited infection of the VM/Dk inbred strain of mice with elk CWD prions has been reported (Lee et al. 2013).

\section{TRANSGENIC MOUSE MODELS OF CWD}

Although CWD is transmissible after intracerebral inoculation of mule deer with incubation
Molecular Mechanisms of CWD Prion Propagation

periods up to $2 \mathrm{yr}$ (Williams and Young 1992), the expense of housing cervids under prion-free conditions for long periods and the highly communicable nature of CWD present significant challenges for using deer as experimental hosts (Mathiason et al. 2006). As noted above, CWD transmissions to other species have yielded mixed results, but are generally inefficient, albeit to varying extents, an effect referred to as the species barrier to prion transmission (Pattison 1965).

Seminal studies in Tg mice with sheep scrapie prions experimentally adapted to mice or Syrian hamsters showed that optimal disease progression requires that the primary structures of the pathogenic form of the prion protein $(\operatorname{PrP})$, referred to as $\operatorname{PrP}^{\mathrm{Sc}}$, and the normal cellular form, referred to as $\mathrm{PrP}^{\mathrm{C}}$, are related (Prusiner et al. 1990; Scott et al. 1993). These studies paved the way for the development of Tg models in which to study human prions (Telling et al. 1995) and subsequently other naturally occurring mammalian prions (for review, see Telling 2011). Studies in Tg mice also underscored that the tertiary structure of $\mathrm{PrP}^{\mathrm{Sc}}$ enciphers strain information (Bessen and Marsh 1994; Telling et al. 1996). Additionally, Tg mice have been used to model interspecies transmission (Vickery et al. 2014), which is generally inefficient and usually characterized by low attack rates with long and variable incubation times upon primary transmission. Relatively facile transmission upon serial passage reflects adaptation in the newly infected species (Telling 2011). The initial barrier to propagation is thought to result from primary structural incompatibilities between donor $\operatorname{PrP}^{\mathrm{Sc}}$ and recipient $\operatorname{PrP}^{\mathrm{C}}$, resulting in inefficient $\operatorname{PrP}^{\mathrm{C}}$ conversion. Ultimately, nascent $\operatorname{PrP}^{\mathrm{Sc}}$ composed of the new host primary structure readily converts $\operatorname{PrP}^{\mathrm{C}}$, and efficient prion propagation ensues in the recipient species.

Using this rationale, several Tg mouse models expressing either elk or deer $\operatorname{PrP}$ have been produced in which the species barrier to CWD has been eliminated. Prototype Tg mice expressing deer $\operatorname{PrP}$, designated $\operatorname{Tg}(\mathrm{CerPrP}) 1536^{+/-}$ (Browning et al. 2004) and referred to here as $\operatorname{Tg}($ DeerPrP $)$, recapitulated the cardinal neuropathological, clinical, and biochemical features of CWD, an observation subsequently con- 
firmed in comparable Tg mouse models expressing deer or elk PrP (Kong et al. 2005; LaFauci et al. 2006; Tamgüney et al. 2006; Meade-White et al. 2007; Angers et al. 2009). The generation of CWD-susceptible Tg mice, in concert with the development of PMCA-based approaches for amplifying CWD infectivity using $\mathrm{PrP}^{\mathrm{C}}$ expressed in the CNS of those mice (Green et al. 2008a; Meyerett et al. 2008) has also provided crucial information about the biology of CWD and cervid prions. Amplification in vitro was shown to maintain CWD prionstrain properties and provided a means of generating novel cervid prion strains (Kurt et al. 2007, 2009; Green et al. 2008a; Meyerett et al. 2008).

Studies in Tg mice and in vitro amplification approaches have also facilitated our understanding of the mechanism of CWD transmission among deer and elk (Mathiason et al. 2006; Haley et al. 2009a,b; Tamgüney et al. 2009). Transmission studies in $\operatorname{Tg}($ DeerPrP $)$ and similar lines of $\mathrm{Tg}$ mice showed that CWD prions were present in urine, feces, and saliva (Tamgüney et al. 2006; Haley et al. 2009a), and these findings were substantiated by in vitro amplification techniques (Haley et al. 2009a; Pulford et al. 2012; Henderson et al. 2013).

$\mathrm{Tg}$ approaches in mice have been essential to assessing the potential risk of human exposure to CWD prions (Angers et al. 2006, 2009; Race et al. 2009b). For the first time, the availability of CWD-susceptible Tg mouse models has also provided a means of quantifying CWD infectivity by end-point titration (Angers et al. 2009).

\section{GENERAL INSIGHTS INTO THE MECHANISM OF PRION PROPAGATION FROM CWD- SUSCEPTIBLE TRANSGENIC MOUSE MODELS}

Effects of Polymorphisms in the Unstructured $\mathrm{N}$ Terminus of PrP

As shown in other species in which prion diseases occur naturally, susceptibility to CWD is highly dependent on polymorphic variation in deer and elk PRNP. Polymorphisms at codons 95 (glutamine [Q] or histidine $[\mathrm{H}]$ ) (Johnson et al. 2003), 96 (glycine [G] or serine [S]) (Raymond et al. 2000; Johnson et al. 2003), and 116 (alanine [A] or G) (Heaton et al. 2003) in whitetailed deer have been reported. Although all major genotypes were found in deer with CWD, the Q96, G96, A116 allele (QGA) was more frequently found in CWD-affected deer than the QSA allele (Johnson et al. 2003; O'Rourke et al. 2004), suggesting a protective effect of the counterpart polymorphisms. The elk PRNP coding sequence is polymorphic at codon 132, encoding either methionine (M) or leucine (L) (Schätzl et al. 1997; O’Rourke et al. 1999). This position is equivalent to human PRNP codon 129. Studies of free-ranging and captive elk with CWD (O'Rourke et al. 1999), as well as oral transmission experiments (Hamir et al. 2006c; O’Rourke et al. 2007), indicate that the $\mathrm{L} 132$ allele protects against CWD.

Tg mouse modeling provides a means of assessing the role of these cervid PrP gene polymorphisms on CWD pathogenesis. In recent work combining studies in Tg mice, the natural host, cell-free prion amplification, and molecular modeling approaches, we analyzed the effects of deer polymorphic amino-acid variations on CWD propagation and susceptibility to prions from different species (Angers et al. 2014). Reflecting the general authenticity of the Tg modeling approach, the properties of CWD prions were faithfully maintained in deer following their passage through Tg mice expressing cognate PrP. Moreover, the protective influences of naturally occurring PrP polymorphisms on CWD susceptibility were accurately reproduced in $\mathrm{Tg}$ mice or during cell free amplification. The resistance to CWD of $\mathrm{Tg}$ mice expressing deer $\mathrm{PrP}$ with serine at residue 96, referred to as $\operatorname{Tg}($ DeerPrP-S96)7511 mice, is consistent with previously generated tg60 mice expressing serine at residue 96 (Meade-White et al. 2007). In the studies of Angers and colleagues, whereas substitutions at residues 95 and 96 affected CWD propagation, their protective effects were overridden during replication of sheep prions in Tg mice and, in the case of residue 96 , deer.

To more fully address the influence of the elk 132 polymorphism, transmissibility of CWD prions was assessed in Tg mice expressing cervid $\mathrm{PrP}^{\mathrm{C}}$ with leucine or methionine at residue 132 
(Green et al. 2008b). Although Tg mice expressing leucine at residue 132 afforded partial resistance to CWD, Sheep Scrapie Brain Pool (SSBP)/ 1 sheep scrapie prions transmitted efficiently to these mice, suggesting that the elk 132 polymorphism also controls prion susceptibility at the level of prion-strain selection. The contrasting ability of CWD and SSBP/ 1 prions to overcome the inhibitory effects of leucine at residue 132 allele is reminiscent of studies describing the effects of the human codon 129 methionine $(\mathrm{M})$ /valine $(\mathrm{V})$ polymorphism on $\mathrm{vCJD} / \mathrm{BSE}$ prion propagation in Tg mice expressing human PrP, which concluded that human PrP with valine at residue 129 severely restricts propagation of the BSE prion strain (Wadsworth et al. 2004). It therefore appears that amino-acid substitutions in the unstructured region of $\mathrm{PrP}$ affect $\mathrm{PrP}^{\mathrm{C}}$-to- $\mathrm{PrP}^{\mathrm{Sc}}$ conversion in a strain-specific manner.

The susceptibility of $\mathrm{Tg}$ (DeerPrP-S96)7511 mice, albeit with incomplete attack rates and long incubation times, is at odds with previous work showing complete resistance of tg60 mice, which express the same deer PrP variant (Meade-White et al. 2007; Race et al. 2011). This apparent discrepancy is most likely related to the low transgene expression in tg60 mice, which is reported to be $70 \%$ of the levels found in deer. CWD occurs naturally in deer homozygous for the PrP-S96 allele (Keane et al. 2008), which is clearly inconsistent with this substitution's completely protective effect, suggesting that $\operatorname{Tg}($ DeerPrP-S96)7511 mice represent an accurate Tg model in which to assess the effects of the S96 substitution.

In accordance with the role of this region in strain selection, in subsequent studies, Tg mice expressing wild-type deer PrP (tg33) or tg60 were challenged with CWD prions from experimentally infected deer with varying polymorphisms at residues 95 and 96 (Duque Velásquez et al. 2015). Passage of deer CWD prions into $\operatorname{tg} 33$ mice resulted in $100 \%$ attack rates, with CWD prions from deer expressing H95 or S96 having significantly longer incubation periods. Remarkably, otherwise resistant tg60 mice (Meade-White et al. 2007; Race et al. 2011) developed disease only when inoculated with pri- ons from deer expressing H95/Q95 and H95/ S96 PrP genotypes. Serial passage in tg60 mice resulted in propagation of a novel CWD strain, referred to as $\mathrm{H}^{+} 5^{+}$, whereas transmission to tg33 mice produced two disease phenotypes consistent with propagation of two strains.

Effects of Residues in a Discontinuous Epitope Formed by Interactions between a $\beta 2-\alpha 2$ Loop and $\alpha$-Helix 3

High-resolution structural studies showed that the loop region linking the second $\beta$-sheet $(\beta 2)$ with the $\alpha 2$-helix $(\alpha 2)$ of cervid PrP is extremely well defined compared with most other species, increasing the possibility that this structural characteristic correlates with the unusually facile contagious transmission of CWD (Gossert et al. 2005). Tg mice expressing mouse PrP in which the $\beta 2-\alpha 2$ loop was replaced by the corresponding region from cervid species spontaneously developed prion disease (Sigurdson et al. 2009). Additional studies consistently point to the importance of the $\beta 2-\alpha 2$ loop in regulating transmission barriers, including that of humans to CWD (Kurt et al. 2009, 2014, 2015; Sigurdson et al. 2010).

Subsequent work suggested a more complex mechanism in which the $\beta 2-\alpha 2$ loop participates with the distal region of $\alpha$-helix 3 to form a solvent-accessible contiguous epitope (Pérez et al. 2010). These and later studies (Christen et al. 2009) ascribed greater importance to the plasticity of this discontinuous epitope. For example, substitution of aspartic acid (D) found in horse, which contains a similarly structured loop region, with serine (S) at residue 170 of mouse (elk PrP numbering), increased not only the structural order of the loop, but also the long-range interaction with tyrosine $(\mathrm{Y})$ at residue 228 in $\alpha$-helix 3. Underscoring the importance of long-range $\beta 2-\alpha 2 \operatorname{loop} / \alpha$-helix 3 interactions, similar structural connections occur between this residue, which is alanine (A) in Tammar wallaby PrP, and residue 169 in the $\beta 2-\alpha 2$ loop (Christen et al. 2009). Stabilizing long-range interactions between the $\beta 2-\alpha 2$ loop and $\alpha$-helix 3 also occur in rabbit $\operatorname{PrP}$, a species generally regarded as resistant to 
prion infection. X-ray crystallographic analyses showed that the rabbit $\beta 2-\alpha 2$ loop is clearly ordered and indicated that hydrophobic interactions between the side chains of valine $(\mathrm{V})$ at residue 169, and in this case Y221 (elk PrP numbering) of $\alpha$-helix 3 , contributed to the stability of the $\beta 2-\alpha 2$ loop/ $\alpha$ helix 3 epitope (Khan et al. 2010).

In mule deer, polymorphism at codon 225 encoding $\mathrm{S}$ or phenylalanine (F) influences CWD susceptibility, with the $225 \mathrm{~F}$ allele being relatively protective. The occurrence of CWD was found to be 30 -fold higher in deer homozygous for serine at position 225 (225SS) than in heterozygous (225SF) animals; the frequency of 225SF and 225FF genotypes in CWD-negative deer was $9.3 \%$, but only $0.3 \%$ in CWDpositive deer (Jewell et al. 2005). Recent studies comparing CWD susceptibility in mule deer with either of the residue 225 genotypes, $225 \mathrm{SS}$ or $225 \mathrm{FF}$, showed that $225 \mathrm{FF}$ mule deer had differences in clinical disease presentation as well as subtler atypical traits (Wolfe et al. 2014). Immediately adjacent to the protective mule deer PrP polymorphism at 225, residue 226 encodes the singular primary structural difference between Rocky Mountain elk and deer PrP. Elk PrP contains glutamate (E) at this position, and deer $\operatorname{PrP}$ contains glutamine $(\mathrm{Q})$.

Recent findings show that residues 225 and 226 play a critical role in $\mathrm{PrP}^{\mathrm{C}}$-to- $\mathrm{PrP}^{\mathrm{Sc}}$ conversion and strain propagation, but the effects are distinct from those produced by the H95Q, G95S, and M132L polymorphisms (Angers et al. 2014). Structural analyses confirm that residues 225 and 226 are located in the distal region of $\alpha$-helix 3 that participates with the $\beta 2-\alpha 2$ loop to form a solvent-accessible contiguous epitope (Pérez et al. 2010). Consistent with the role of this epitope in $\operatorname{PrP}$ conversion, these polymorphisms severely impact replication of both SSBP/1 and, to variable degrees, CWD. In the case of $\mathrm{Tg}$ mice expressing deer $\operatorname{PrP}$ with phenylalanine at 225 , referred to as $\mathrm{Tg}$ (DeerPrP-F225), SSBP/1 incubation times were prolonged threefold, whereas inoculation with CWD produced incomplete attack rates and prolonged and variable incubation times in the small numbers of mice that did develop disease. In those $\operatorname{Tg}($ DeerPrP-F225) mice that did succumb to CWD, $\operatorname{PrP}^{\mathrm{Sc}}$ distribution patterns were altered compared with $\operatorname{Tg}($ DeerPrP) mice.

To address the effects of the substitution of glutamate for glutamine at residue 226, we assessed whether $\mathrm{Tg}$ mice expressing wild-type elk or deer PrP differed in their responses to CWD. These studies showed that differences at residue 226 also affected CWD replication, but to a lesser degree than the residue 225 polymorphism, with disease onset prolonged by $20 \%-$ $46 \%$ in CWD-inoculated $\mathrm{Tg}($ DeerPrP $)$ compared with $\mathrm{Tg}(\mathrm{ElkPrP})$ mice, and $\mathrm{PrP}^{\mathrm{Sc}}$ distribution and neuropathology varying in each case (Angers et al. 2009). In contrast to $\operatorname{Tg}($ DeerPrP) mice, which are susceptible to SSBP/1 (Green et al. 2008b), $\mathrm{Tg}(\mathrm{ElkPrP})$ mice were completely resistant (Angers et al. 2009), although the resistance of elk $\mathrm{PrP}^{\mathrm{C}}$ to propagation of SSBP/1 was overcome following adaptation in deer or $\mathrm{Tg}($ DeerPrP $)$ mice. Passage in $\mathrm{Tg}$ mice expressing E226 or Q226 profoundly affected the ability of SSBP/1 to reinfect Tg mice expressing sheep $\operatorname{PrP}^{\mathrm{C}}$. These studies paralleled aspects of our previously published work indicating that amino-acid differences at residue 226 controlled the manifestation of CWD quasispecies or closely related strains (Angers et al. 2010). These findings therefore collectively point to an important role for residues 225 and 226 in $\mathrm{PrP}^{\mathrm{C}}$ to- $\mathrm{PrP}^{\mathrm{Sc}}$ conversion and the manifestation of prion-strain properties. They substantiate the view that long-range interactions between the $\beta 2-\alpha 2$ loop and $\alpha$-helix 3 provide protection against prion infection and suggest a likely mechanism to account for the protective effects of the F225 polymorphism. Molecular dynamics analyses (Angers et al. 2014) showed that the S225F and E226Q substitutions in deer alter the orientations of D170 in the $\beta 2-\alpha 2$ loop and Y228 in $\alpha$-helix 3. This structural change allows hydrogen bonding between the side chains of these residues, which results in reduced plasticity of the $\beta 2-\alpha 2$ loop $/ \alpha$-helix 3 epitope compared with deer or elk PrP structures. This suggests that the increased stability of this tertiary structural epitope precludes $\mathrm{PrP}^{\mathrm{C}}$-to$\mathrm{PrP}^{\mathrm{Sc}}$ conversion of deerPrP-F225. 


\section{CELL CULTURE MODELS OF CWD}

\section{Therapeutic Approaches}

Based on observations showing that rabbit kidney epithelial (RK13) cells engineered to express sheep PrP were capable of propagating scrapie prions (Vilette et al. 2001), cloned RK13 cells expressing elk PrP were developed. A highly susceptible clone producing $\mathrm{PrP}^{\mathrm{Sc}}$, referred to as Elk- $21^{+}$, was isolated in which CWD infection was maintained for more than 100 passages (Bian et al. 2010). Inoculation of CWD-susceptible $\mathrm{Tg}(\mathrm{ElkPrP})$ mice with prions from Elk- $21^{+}$ cells resulted in disease transmission with clinical and neuropathological features identical to CWD.

This development provided a unique and convenient means of exploring CWD therapeutics. Our first approach was to assess the efficacy of compounds with known effects on rodent prions. Consistent with its effect on mouse prion infectivity, sustained treatment of Elk- $21^{+}$ cells with dextran sulfate 500 (DS-500) resulted in $\mathrm{PrP}^{\mathrm{Sc}}$ clearance, which did not reemerge in the resulting Elk-21- cells after more than 40 passages, and inoculation of susceptible $\mathrm{Tg}$ mice showed that Elk-21 ${ }^{-}$cells were cured of CWD prion infection (Bian et al. 2010). In stark contrast to its well-documented inhibitory effects on $\mathrm{PrP}^{\mathrm{Sc}}$ accumulation in cells chronically infected with experimentally adapted rodent prions (Doh-Ura et al. 2000; Korth et al. 2001; Barret et al. 2003; Ryou et al. 2003; Klingenstein et al. 2006; Fasano et al. 2008; Mays et al. 2012 ), quinacrine increased elk and deer $\mathrm{PrP}^{\mathrm{Sc}}$ accumulation and raised prion titers in cells persistently infected with CWD prions (Bian et al. 2014). These findings show that a compound with demonstrated, albeit transient, efficacy against a strain in one species acts to directly enhance prion replication in a different species and produces prions with novel biological properties. This means that the effects of "antiprion" compounds are clearly species/strain dependent, in that drugs found to restrain prions in one situation may improve replicative ability in another. These findings force a reconsideration of current strategies to screen antiprion drugs. In particular, it seems imperative that
Molecular Mechanisms of CWD Prion Propagation

cells with susceptibilities to cervid, ovine, bovine, and human prions be used to identify drugs capable of treating prions affecting those species.

Studies with the 2-aminothiazole referred to as IND24 showed that mice treated with this compound and infected with mouseadapted scrapie had longer survival times, but that treatment led to the emergence of drugresistant variants (Berry et al. 2013). IND24 doubled the incubation times for $\mathrm{Tg}$ mice infected with CWD prions, and extensive analyses indicated that the CWD prions were not altered by IND24 treatment. This is significant because these results reveal efficacy of a therapeutic on a naturally occurring prion, in a system replicating such prions, and suggest that IND24 may be a viable candidate for treating CWD in natural hosts (Berry et al. 2015).

With respect to therapeutic options for CWD, white-tailed deer orally vaccinated with attenuated Salmonella expressing PrP and orally challenged with CWD had a significant prolongation of the incubation period, with one deer remaining asymptomatic by several sensitive criteria (Goñi et al. 2015).

\section{Cell-Based CWD Quantification}

Elk-21 ${ }^{-}$cells were used to develop a novel cellbased assay for CWD prion quantification, analogous to the scrapie cell assay developed by Weissmann and colleagues (Klöhn et al. 2003) as a facile alternative to in vivo CWD prion quantification. This cell-based assay is referred to as the cervid prion cell assay (CPCA). Detection and quantification of cervid prions, including naturally occurring CWD prions and experimentally adapted cervid prion strains, was made possible using the CPCA (Bian et al. 2010).

In the CPCA, CWD prion-susceptible Elk$21^{-}$cells in 96-well plates are exposed to serial dilutions of the prion-containing sample for $4 \mathrm{~d}$, grown to confluence, split at a ratio of $1: 8$, grown to confluence once more, and split similarly again. When the cells have reached confluence after the second split, 20,000 cells are filtered onto membranes of Elispot plates, and 
the proportion of cells containing proteaseresistant $\mathrm{CerPrP}^{\mathrm{Sc}}$ is identified by an enzymelinked immunosorbent assay (ELISA) using automated counting equipment (Elispot). Inclusion of RK13 cells stably transfected with empty vector showed that positive spots detected after three splits were the result of newly generated $\mathrm{CerPrP}{ }^{\mathrm{Sc}}$. Although $\mathrm{CerPrP} \mathrm{P}^{\mathrm{Sc}}$ purification as described for other CWD cell-culture systems (Raymond et al. 2006) was not a prerequisite for sustained cellular infection, expression of retroviral Gag facilitated prion susceptibility, and cell cloning was also critical.

This cell-based approach also facilitated novel means of assessing prion-strain properties, specifically conformational stability analyses of $\mathrm{PrP}^{\mathrm{Sc}}$ (Peretz et al. 2001). Apart from limited investigations in infected cell cultures (Ghaemmaghami et al. 2011), such analyses are generally conducted on $\mathrm{PrP}^{\mathrm{Sc}}$ produced in infected brains. This constraint relates, in large part, to relatively low $\mathrm{PrP}^{\mathrm{Sc}}$ levels in infected cell cultures and a paucity of sensitive cell-based analytical approaches. A cell-based conformational stability assay (C-CSA) circumvents these drawbacks because it provides the advantage of direct in situ detection of $\operatorname{PrP}^{\mathrm{Sc}}$ without isolation or purification and is a quantitative, sensitive, and accurate means of discerning the unfolding characteristics of $\operatorname{PrP}^{\mathrm{Sc}}$ (Bian et al. 2014).

\section{CWD STRAINS}

Although our seminal studies in $\mathrm{Tg}$ mice (Browning et al. 2004) and subsequent work (LaFauci et al. 2006) raised the possibility of CWD strain variation, the limited number of isolates and the lack of detailed strain analyses in these studies means that this hypothesis remained speculative. Subsequent studies supported the feasibility of using $\operatorname{Tg}($ DeerPrP) mice for characterizing naturally occurring CWD strains, as well as novel cervid prions generated by PMCA (Green et al. 2008a). To address whether different CWD strains occur in various geographical locations or in different cervid species, bioassays in $\mathrm{Tg}$ mice were used to analyze CWD in a large collection of captive and wild mule deer, white-tailed deer, and elk from various geographical locations in North America (Angers et al. 2010). These findings provided substantial evidence for two prevalent CWD prion strains, referred to as CWD1 and CWD2, with different clinical and neuropathological properties. Remarkably, primary transmission of CWD prions from elk produced either CWD1 or CWD2 profiles, whereas transmission of deer inocula favored the production of mixed intra-study incubation times and CWD1 and CWD2 neuropathologies. These findings indicate that elk may be infected with either CWD1 or CWD2, whereas deer brains tend to harbor CWD1/CWD2 strain mixtures.

The different primary structures of deer and elk $\operatorname{PrP}$ at residue 226 provide a framework for understanding these differences in strain profiles of deer and elk. Because of the role played by residue 226 , the description of a lysine $(\mathrm{K})$ polymorphism at this position in deer (Johnson et al. 2006b) and its possible role on strain stability may be significant. It is unknown whether CWD1 and CWD2 interfere or act synergistically or whether their coexistence contributes to the unparalleled efficiency of CWD transmission. Interestingly, transmission results reported in previous studies suggest that cervid brain inocula might be composed of strain mixtures (Tamgüney et al. 2006).

Additional studies support the existence of multiple CWD strains. CWD has also been transmitted, albeit with varying efficiency, to $\mathrm{Tg}$ mice expressing mouse PrP (Sigurdson et al. 2006; Tamgüney et al. 2006). In the Sigurdson et al. study, a single mule deer isolate produced disease in all inoculated Tga20 mice, which express mouse $\mathrm{PrP}$ at high levels. On successive passages, incubation times dropped to $\sim 160$ d. In the second study, one elk isolate from a total of eight deer and elk CWD isolates induced disease in $75 \%$ of inoculated $\operatorname{Tg} 4053$ mice, which also overexpress mouse PrP. The distribution of lesions in both studies appeared to resemble the CWD1 pattern. Low efficiency CWD prion transmission was also recorded in hamsters and $\mathrm{Tg}$ mice expressing Syrian hamster PrP (Raymond et al. 2007). In that study, during serial passage of mule deer CWD, fast- and slow-incubation-time strains 
with different patterns of brain pathology and $\mathrm{PrP}^{\mathrm{Sc}}$ deposition were also isolated. In other studies, serial passages of CWD from whitetailed deer into Tg mice expressing hamster PrP, and then Syrian golden hamsters, produced a strain, referred to as "wasting" (WST), characterized by a prominent preclinical wasting disease similar to cachexia, which the investigators propose results from a prion-induced endocrinopathy (Bessen et al. 2011). These same investigators identified a second strain, defined as "cheeky" (CKY), derived from infection of Tg mice that express hamster PrP (Crowell et al. 2015). The CKY strain had a shorter incubation period than WST, but after transmission to hamsters, the incubation period of CKY became $\sim 150 \mathrm{~d}$ longer than WST. In this case, $\mathrm{PK}$ digestion revealed strain-specific $\mathrm{PrP}^{\mathrm{Sc}}$ signatures that were maintained in both hosts, but the solubility and conformational stability of $\mathrm{PrP}^{\mathrm{Sc}}$ differed for the CWD strains in a hostdependent manner. In addition to supporting the view that there are multiple CWD strains, these findings suggest the importance of hostspecific pathways, independent of $\mathrm{PrP}$, that participate in the selection and propagation of distinct strains.

Studies in cell culture also support the existence of CWD strains. Quinacrine altered the transmission properties of CWD prions, as well as the biochemical characteristics of the constitutive $\operatorname{PrP}^{\mathrm{Sc}}$ (Bian et al. 2014). Despite accumulating significantly higher prion titers, quinacrine-treated (Q-CWD) prions from Elk- $21^{+}$cells produced prolonged incubation times in $\operatorname{Tg}($ DeerPrP $)$ and $\operatorname{Tg}($ ElkPrP $)$ mice compared with CWD prions in untreated Elk- $21^{+}$cells. Because the kinetics of disease onset in prion-infected animals is inversely related to the titer of a given prion strain, this unusual outcome is consistent with quinacrine affecting the intrinsic properties of the CWD prion. In accordance with this notion, although the deposition patterns of $\operatorname{PrP}^{\mathrm{Sc}}$ in the brains of diseased $\mathrm{Tg}($ DeerPrP $)$ and $\mathrm{Tg}($ ElkPrP $)$ mice receiving prions from Elk- $21^{+}$are concordant with our previously published descriptions following transmission of naturally occurring or PMCA-generated CWD prions (Green et al. 2008a), these distinctive patterns were not recapitulated in either line of $\mathrm{Tg}$ mice receiving Q-CWD prions. Although prion incubation times and neuronal targeting are the biological criteria by which prion strains are classically defined, subsequent studies showed that strain properties are enciphered within the conformation of $\operatorname{PrP}^{\mathrm{Sc}}$ (Telling et al. 1996; Green et al. 2008a), and cervid prion incubation times positively correlate with $\operatorname{PrP}^{\mathrm{Sc}}$ conformational stability (Green et al. 2008a). It is therefore significant that the longer incubation times of Q-CWD prions and altered patterns of $\mathrm{PrP}^{\mathrm{Sc}}$ deposition in both $\mathrm{Tg}$ models were associated with an increase in the relative stability of $\mathrm{PrP}^{\mathrm{Sc}}$ conformers constituting Q-CWD prions.

The properties of Q-CWD prions provided convincing evidence for conformational mutations that were suggested, but could not be observed, in previous studies of mouse-adapted scrapie prions in cell cultures treated with swainsonine, an inhibitor of Golgi $\alpha$-mannosidase II ( Li et al. 2010). Because the swainsonineinduced properties of cell-derived mouse prions reverted to their original characteristics when propagated in vivo, and there were no detectable differences in the conformations of $\mathrm{PrP}^{\mathrm{Sc}}$ generated under conditions of swainsonine treatment compared with untreated cells, claims of strain mutation were indirectly based on the differing properties of prions from swainsonine-treated and untreated cells using a cell panel assay. In contrast, CWD and QCWD prions are comprised of distinct $\mathrm{PrP}^{\mathrm{Sc}}$ conformers that produce discernable phenotypes in two lines of Tg mice.

In accordance with western blot-based analyses showing higher conformational stabilities of $\mathrm{PrP}^{\mathrm{Sc}}$ produced in the brains of CWDinfected $\operatorname{Tg}($ DeerPrP $)$ mice compared with $\mathrm{Tg}($ ElkPrP) mice (Angers et al. 2010), C-CSA confirmed that the conformation of deer $\mathrm{PrP}^{\mathrm{Sc}}$ in $\mathrm{RK} 13$ cells expressing deer $\operatorname{PrP}\left(\mathrm{RKD}^{+}\right)$was more stable than elk $\mathrm{PrP}^{\mathrm{Sc}}$ produced during infection of Elk- $21^{+}$. Because Elk- $21^{+}$and RKD ${ }^{+}$ propagated CWD prions from the same source, differences in conformational stability result from the effects of residue 226, the sole primary structural difference between elk and deer PrP. 
J.A. Moreno and G.C. Telling

\section{WHAT IS THE THREAT OF CWD TO HUMANS?}

The identification and characterization of distinct CWD strains, and the influence of PrP primary structure on their stabilities, is important when considering the potential for interspecies transmission. The appearance of vCJD following human exposure to BSE (Bruce et al. 1997; Hill et al. 1997) raises public health concerns about the human species barrier to other animal prion diseases, particularly CWD. North American hunters harvest thousands of deer and elk each year, and it is not currently mandatory that these animals are tested for CWD; therefore, it is likely that humans consume CWD prions. Additionally, CWD prions have been shown in the skeletal muscle and fat of deer (Angers et al. 2006; Race et al. 2009b). The substantial market for elk antler velvet in traditional Asian medicine also warrants concern (Angers et al. 2009).

Estimates of the zoonotic potential of CWD are currently mixed. Surveillance currently shows no evidence of transmission to humans (Belay et al. 2004; Mawhinney et al. 2006). Although initial cell-free conversion studies suggested that the ability of CWD prions to transform human $\mathrm{PrP}^{\mathrm{C}}$ into protease-resistant $\operatorname{PrP}\left(\mathrm{PrP}^{\mathrm{Sc}}\right)$ was low (Raymond et al. 2000), subsequent results showed that cervid $\mathrm{PrP}^{\mathrm{Sc}}$ induced the conversion of human $\operatorname{PrP}^{\mathrm{C}}$ by PMCA, following CWD prion-strain stabilization by successive passages in vitro or in vivo (Barria et al. 2011). These results have implications for the human species barrier to CWD and underscore the role of strain adaptation on interspecies transmission barriers. Additional studies using $\mathrm{Tg}$ mice expressing human $\operatorname{PrP}^{\mathrm{C}}$ showed that CWD prions failed to induce disease following intracerebral infection (Kong et al. 2005; Tamgüney et al. 2006; Sandberg et al. 2010). However, CWD transmission was reported in squirrel monkeys (Saimiri sciureus) after intracerebral inoculation (Marsh et al. 2005; Race et al. 2009a). Moreover, using RTQuIC to model the transmission barrier of CWD to human rPrP, the work of Davenport and colleagues suggests that, at the level of protein-protein interactions, CWD adapts to a new species more readily than does BSE and that the barrier preventing transmission of CWD to humans may be less robust than estimated (Davenport et al. 2015).

\section{CONCLUSIONS AND FUTURE PROSPECTS}

Some 15 years ago, CWD was perhaps the least understood of all the prion diseases in animals and humans. Known to be highly contagious, its origins and mode of transmission were unclear, and it was not known whether multiple CWD strains existed or whether CWD prions posed a risk to other animals or humans. The main objectives at that time were to develop rapid and sensitive bioassays for CWD prions and to experimentally address the risks that CWD prions posed to humans and other species. Developing Tg mice that were the first reliable bioassay for rapid and sensitive detection of CWD prions was a significant advance. With these resources in hand, investigators have been able to obtain important information about CWD pathogenesis and the molecular mechanisms of prion propagation, species barriers, and strains. Using CWD-susceptible Tg mice, it has become possible to bioassay CWD prions in tissues, body fluids, and secretions of deer and elk, which have provided insights into the mode of transmission of this highly contagious disease. The study of intermammalian species barriers in Tg mice allows investigators to model the risks posed to humans and livestock from exposure to CWD prions, and this information helps facilitate management decisions designed to minimize interspecies prion transmission. During this time, the development of more facile, sensitive approaches to amplify prions in vitro, such as PMCA and RT-QuIC, have revolutionized our ability to detect prions, even at extremely low titers. In concert, cell culture models have provided an alternate means of CWD titration that has largely superseded bioassay in $\mathrm{Tg}$ mice and has provided insights into strategies for developing compounds that inhibit CWD propagation. The development of compounds such as IND24 provides significant optimism for treating this currently incurable 
disease. Finally, studies of CWD using these newly developed tools have provided unexpected mechanistic insights into $\mathrm{PrP}^{\mathrm{C}}$-to- $\mathrm{PrP}^{\mathrm{Sc}}$ conversion, particularly the role of the $\beta 2-\alpha 2$ loop $/ \alpha$-helix 3 epitope and the proposal that prion strains exist as a continuum of conformational quasispecies.

Looking toward the future, although many enigmatic issues surrounding the biology of CWD have been addressed and resolved over the last decade and a half, substantial questions remain. First, it is unclear whether management of this highly contagious, lethal disease will be successful in the coming decades. To date, the geographical areas and numbers of host species affected by CWD have been expanding unchecked. Given the high densities of deer populations in many areas of North America and Europe, and the persistence of CWD infectivity in the environment, there is little reason to suspect that this trend will not continue. The possibility that CWD will establish a foothold in the large populations of migratory caribou in northern Canada is of particular concern given the reliance of First Nation peoples on these and other cervid species. Beyond North America, expansion of CWD to other countries, as occurred in the case of the Republic of Korea, and more recently Norway, is also of importance, although the limited amount of surveillance that has been put in place to monitor disease would appear to be at odds with these concerns. Although Tg models have been extremely valuable as a means of detecting and studying CWD prions, they have significant drawbacks when it comes to reproducing features of peripheral pathogenesis in the natural host. Because this feature most likely influences the highly contagious nature of disease, the development of tractable model systems in which to accurately study the parameters governing peripheral CWD pathogenesis and contagious transmission in the wild is a high priority.

Second, our studies suggest that CWD-infected deer, elk, or moose produce prions with different biological characteristics. This finding raises several important questions, including the evolutionary effects of passage among these species on the infectious properties of CWD and whether CWD prions arising from these different sources have varying zoonotic potentials. Related to this question, and given the impact of strain properties on interspecies transmission, systematically addressing the zoonotic potential, as well as the tissue distributions of newly recognized CWD strains, including CWD1 and CWD2 (Angers et al. 2010), would appear to remain high priorities. The transmission of BSE to humans in the form of vCJD underscores the potential and the unpredictability of newly emergent prions to cause disease in humans that consume, or are otherwise exposed to, CWD prions. The best that can be said about the current scientific evidence surrounding this issue is that the zoonotic potential of CWD remains uncertain.

\section{REFERENCES}

Almberg ES, Cross PC, Johnson CJ, Heisey DM, Richards BJ. 2011. Modeling routes of chronic wasting disease transmission: Environmental prion persistence promotes deer population decline and extinction. PLoS One 6: e19896.

Angers RC, Browning SR, Seward TS, Sigurdson CJ, Miller MW, Hoover EA, Telling GC. 2006. Prions in skeletal muscles of deer with chronic wasting disease. Science 311: 1117.

Angers RC, Seward TS, Napier D, Green M, Hoover E, Spraker T, O'Rourke K, Balachandran A, Telling GC. 2009. Chronic wasting disease prions in elk antler velvet. Emerg Infect Dis 15: 696-703.

Angers RC, Kang HE, Napier D, Browning S, Seward T, Mathiason C, Balachandran A, McKenzie D, Castilla J, Soto C, et al. 2010. Prion strain mutation determined by prion protein conformational compatibility and primary structure. Science 328: 1154-1158.

Angers R, Christiansen J, Nalls AV, Kang HE, Hunter N, Hoover E, Mathiason CK, Sheetz M, Telling GC. 2014. Structural effects of PrP polymorphisms on intra- and interspecies prion transmission. Proc Natl Acad Sci 111: 11169-11174.

Baeten LA, Powers BE, Jewell JE, Spraker TR, Miller MW. 2007. A natural case of chronic wasting disease in a freeranging moose (Alces alces shirasi). J Wildl Dis 43: 309314.

Barret A, Tagliavini F, Forloni G, Bate C, Salmona M, Colombo L, De Luigi A, Limido L, Suardi S, Rossi G, et al. 2003. Evaluation of quinacrine treatment for prion diseases. J Virol 77: 8462-8469.

Barria MA, Telling GC, Gambetti P, Mastrianni JA, Soto C. 2011. Generation of a new form of human $\operatorname{PrP}^{\mathrm{Sc}}$ in vitro by interspecies transmission from cervid prions. $J$ Biol Chem 286: 7490-7495. 
Bartz JC, Marsh RF, McKenzie DI, Aiken JM. 1998. The host range of chronic wasting disease is altered on passage in ferrets. Virology 251: 297-301.

Belay ED, Maddox RA, Williams ES, Miller MW, Gambetti P, Schonberger LB. 2004. Chronic wasting disease and potential transmission to humans. Emerg Infect Dis 10: 977-984.

Benestad SL, Mitchell G, Simmons M, Ytrehus B, Vikøren T. 2016. First case of chronic wasting disease in Europe in a Norwegian free-ranging reindeer. Vet Res 47: 88.

Berry DB, Lu D, Geva M, Watts JC, Bhardwaj S, Oehler A, Renslo AR, DeArmond SJ, Prusiner SB, Giles K. 2013. Drug resistance confounding prion therapeutics. Proc Natl Acad Sci 110: E4160-E4169.

Berry D, Giles K, Oehler A, Bhardwaj S, DeArmond SJ, Prusiner SB. 2015. Use of a 2-aminothiazole to treat chronic wasting disease in transgenic mice. J Infect Dis 212: S17-S25.

Bessen RA, Marsh RF. 1994. Distinct PrP properties suggest the molecular basis of strain variation in transmissible mink encephalopathy. J Virol 68: 7859-7868.

Bessen RA, Robinson CJ, Seelig DM, Watschke CP, Lowe D, Shearin H, Martinka S, Babcock AM. 2011. Transmission of chronic wasting disease identifies a prion strain causing cachexia and heart infection in hamsters. PLoS One 6: e28026.

Bian J, Napier D, Khaychuck V, Angers R, Graham C, Telling G. 2010. Cell-based quantification of chronic wasting disease prions. J Virol 84: 8322-8326.

Bian J, Kang HE, Telling GC. 2014. Quinacrine promotes replication and conformational mutation of chronic wasting disease prions. Proc Natl Acad Sci 111: 60286033.

Browning SR, Mason GL, Seward T, Green M, Eliason GA, Mathiason C, Miller MW, Williams ES, Hoover E, Telling GC. 2004. Transmission of prions from mule deer and elk with chronic wasting disease to transgenic mice expressing cervid PrP. J Virol 78: 13345-13350.

Bruce ME, Will RG, Ironside JW, McConnell I, Drummond D, Suttie A, McCardle L, Chree A, Hope J, Birkett C, et al 1997. Transmissions to mice indicate that "new variant" CJD is caused by the BSE agent. Nature 389: 498-501.

Christen B, Hornemann S, Damberger FF, Wüthrich K. 2009. Prion protein NMR structure from tammar wallaby (Macropus engenii) shows that the $\beta 2-\alpha 2$ loop is modulated by long-range sequence effects. $J \mathrm{Mol}$ Biol 389: $833-845$.

Conner MM, Miller MW, Ebinger MR, Burnham KP. 2007. A meta-BACI approach for evaluating management intervention on chronic wasting disease in mule deer. Ecol Appl 17: 140-153.

Crowell J, Hughson A, Caughey B, Bessen RA. 2015. Host determinants of prion strain diversity independent of prion protein genotype. J Virol 89: 10427-10441.

Davenport KA, Henderson DM, Bian J, Telling GC, Mathiason CK, Hoover EA. 2015. Insights into chronic wasting disease and bovine spongiform encephalopathy species barriers by use of real-time conversion. J Virol 89: $9524-$ 9531.

Di Bari MA, Nonno R, Castilla J, D’Agostino C, Pirisinu L, Riccardi G, Conte M, Richt J, Kunkle R, Langeveld J, et al.
2013. Chronic wasting disease in bank voles: Characterisation of the shortest incubation time model for prion diseases. PLoS Pathog 9: e1003219.

Doh-Ura K, Iwaki T, Caughey B. 2000. Lysosomotropic agents and cysteine protease inhibitors inhibit scrapieassociated prion protein accumulation. J Virol 74: 48944897.

Dube C, Mehren KG, Barker IK, Peart BL, Balachandran A. 2006. Retrospective investigation of chronic wasting disease of cervids at the Toronto Zoo, 1973-2003. Can Vet J 47: 1185-1193.

Dulberger J, Hobbs NT, Swanson HM, Bishop CJ, Miller MW. 2010. Estimating chronic wasting disease effects on mule deer recruitment and population growth. J Wildl Dis 46: 1086-1095.

Duque Velásquez C, Kim C, Herbst A, Daude N, Garza MC Wille H, Aiken J, McKenzie D. 2015. Deer prion proteins modulate the emergence and adaptation of chronic wasting disease strains. J Virol 89: 12362-12373.

Fasano C, Campana V, Griffiths B, Kelly G, Schiavo G, Zurzolo C. 2008. Gene expression profile of quinacrinecured prion-infected mouse neuronal cells. J Neurochem 105: 239-250.

Fox KA, Jewell JE, Williams ES, Miller MW. 2006. Patterns of $\mathrm{PrP}^{\mathrm{CWD}}$ accumulation during the course of chronic wasting disease infection in orally inoculated mule deer (Odocoileus hemionus). J Gen Virol 87: 3451-3461.

Geremia C, Miller MW, Hoeting JA, Antolin MF, Hobbs NT. 2015. Bayesian modeling of prion disease dynamics in mule deer using population monitoring and capture-recapture data. PLoS One 10: e0140687.

Ghaemmaghami S, Watts JC, Nguyen HO, Hayashi S, DeArmond SJ, Prusiner SB. 2011. Conformational transformation and selection of synthetic prion strains. J Mol Biol 413: 527-542.

Goñi F, Mathiason CK, Yim L, Wong K, Hayes-Klug J, Nalls A, Peyser D, Estevez V, Denkers N, Xu J, et al. 2015. Mucosal immunization with an attenuated Salmonella vaccine partially protects white-tailed deer from chronic wasting disease. Vaccine 33: 726-733.

Gossert AD, Bonjour S, Lysek DA, Fiorito F, Wüthrich K. 2005. Prion protein NMR structures of elk and of mouse elk hybrids. Proc Natl Acad Sci 102: 646-650.

Green KM, Castilla J, Seward TS, Napier DL, Jewell JE, Soto C, Telling GC. 2008a. Accelerated high fidelity prion amplification within and across prion species barriers. PLoS Pathog 4: e1000139.

Green KM, Browning SR, Seward TS, Jewell JE, Ross DL, Green MA, Williams ES, Hoover EA, Telling GC. 2008b. The elk PRNP codon 132 polymorphism controls cervid and scrapie prion propagation. J Gen Virol 89: 598-608.

Haley NJ, Hoover EA. 2015. Chronic wasting disease of cervids: Current knowledge and future perspectives. Annu Rev Anim Biosci 3: 305-325.

Haley NJ, Seelig DM, Zabel MD, Telling GC, Hoover EA. 2009a. Detection of CWD prions in urine and saliva of deer by transgenic mouse bioassay. PLoS One 4: e4848.

Haley NJ, Mathiason CK, Zabel MD, Telling GC, Hoover EA. 2009b. Detection of sub-clinical CWD infection in conventional test-negative deer long after oral exposure to urine and feces from CWD+ deer. PLoS One 4: e7990. 
Haley NJ, Mathiason CK, Carver S, Zabel M, Telling GC, Hoover EA. 2011. Detection of CWD prions in salivary, urinary, and intestinal tissues of deer: Potential mechanisms of prion shedding and transmission. J Virol 85: 6309-6318.

Haley NJ, Carver S, Hoon-Hanks LL, Henderson DM, Davenport KA, Bunting E, Gray S, Trindle B, Galeota J, LeVan I, et al. 2014. Detection of chronic wasting disease in the lymph nodes of free-ranging cervids by real-time quaking-induced conversion. J Clin Microbiol 52: 3237-3243.

Hamir AN, Cutlip RC, Miller JM, Williams ES, Stack MJ, Miller MW, O’Rourke KI, Chaplin MJ. 2001. Preliminary findings on the experimental transmission of chronic wasting disease agent of mule deer to cattle. J Vet Diagn Invest 13: 91-96.

Hamir AN, Miller JM, Cutlip RC, Stack MJ, Chaplin MJ, Jenny AL, Williams ES. 2003. Experimental inoculation of scrapie and chronic wasting disease agents in raccoons (Procyon lotor). Vet Rec 153: 121-123.

Hamir AN, Kunkle RA, Cutlip RC, Miller JM, O’Rourke KI, Williams ES, Miller MW, Stack MJ, Chaplin MJ, Richt JA. 2005. Experimental transmission of chronic wasting disease agent from mule deer to cattle by the intracerebral route. J Vet Diagn Invest 17: 276-281.

Hamir AN, Kunkle RA, Miller JM, Greenlee JJ, Richt JA. 2006a. Experimental second passage of chronic wasting disease $\left(C W D^{\text {mule deer }}\right)$ agent to cattle. J Comp Pathol 134: 63-69.

Hamir AN, Kunkle RA, Cutlip RC, Miller JM, Williams ES, Richt JA. 2006b. Transmission of chronic wasting disease of mule deer to Suffolk sheep following intracerebral inoculation. J Vet Diagn Invest 18: 558-565.

Hamir AN, Gidlewski T, Spraker TR, Miller JM, Creekmore L, Crocheck M, Cline T, O’Rourke KI. 2006c. Preliminary observations of genetic susceptibility of elk (Cervus elaphus nelsoni) to chronic wasting disease by experimental oral inoculation. J Vet Diagn Invest 18: 110-114.

Hamir AN, Miller JM, Kunkle RA, Hall SM, Richt JA. 2007a Susceptibility of cattle to first-passage intracerebral inoculation with chronic wasting disease agent from whitetailed deer. Vet Pathol 44: 487-493.

Hamir AN, Kunkle RA, Miller JM, Cutlip RC, Richt JA, Kehrli ME Jr, Williams ES. 2007b. Age-related lesions in laboratory-confined raccoons (Procyon lotor) inoculated with the agent of chronic wasting disease of mule deer. $J$ Vet Diagn Invest 19: 680-686.

Hamir AN, Kunkle RA, Nicholson EM, Miller JM, Hall SM, Schoenenbruecher H, Brunelle BW, Richt JA. 2008. Preliminary observations on the experimental transmission of chronic wasting disease (CWD) from elk and whitetailed deer to fallow deer. J Comp Pathol 138: 121-130.

Heaton MP, Leymaster KA, Freking BA, Hawk DA, Smith TP, Keele JW, Snelling WM, Fox JM, Chitko-McKown CG, Laegreid WW. 2003. Prion gene sequence variation within diverse groups of U.S. sheep, beef cattle, and deer. Mamm Genome 14: 765-777.

Heisey DM, Mickelsen NA, Schneider JR, Johnson CJ, Johnson CJ, Langenberg JA, Bochsler PN, Keane DP, Barr DJ. 2010. Chronic wasting disease (CWD) susceptibility of several North American rodents that are sympatric with cervid CWD epidemics. J Virol 84: 210-215.
Henderson DM, Manca M, Haley NJ, Denkers ND, Nalls AV, Mathiason CK, Caughey B, Hoover EA. 2013. Rapid antemortem setection of CWD prions in seer saliva. PLoS One 8: e74377.

Henderson DM, Davenport KA, Haley NJ, Denkers ND, Mathiason CK, Hoover EA. 2015. Quantitative assessment of prion infectivity in tissues and body fluids by real-time quaking-induced conversion. J Gen Virol 96: $210-219$.

Hill AF, Desbruslais M, Joiner S, Sidle KC, Gowland I, Collinge J, Doey LJ, Lantos P. 1997. The same prion strain causes vCJD and BSE. Nature 389: 448-450.

Jewell JE, Conner MM, Wolfe LL, Miller MW, Williams ES. 2005. Low frequency of PrP genotype 225SF among freeranging mule deer (Odocoileus hemionus) with chronic wasting disease. J Gen Virol 86: 2127-2134.

Jewell JE, Brown J, Kreeger T, Williams ES. 2006. Prion protein in cardiac muscle of elk (Cervus elaphus nelsoni) and white-tailed deer (Odocoileus virginianus) infected with chronic wasting disease. J Gen Virol 87: 3443-3450.

Johnson C, Johnson J, Clayton M, McKenzie D, Aiken J. 2003. Prion protein gene heterogeneity in free-ranging white-tailed deer within the chronic wasting disease affected region of Wisconsin. J Wildl Dis 39: 576-581.

Johnson CJ, Phillips KE, Schramm PT, McKenzie D, Aiken JM, Pedersen JA. 2006a. Prions adhere to soil minerals and remain infectious. PLoS Pathog 2: e32.

Johnson C, Johnson J, Vanderloo JP, Keane D, Aiken JM, McKenzie D. 2006b. Prion protein polymorphisms in white-tailed deer influence susceptibility to chronic wasting disease. J Gen Virol 87: 2109-2114.

Johnson CJ, Pedersen JA, Chappell RJ, McKenzie D, Aiken JM. 2007. Oral transmissibility of prion disease is enhanced by binding to soil particles. PLoS Pathog 3: e93.

Joly DO, Ribic CA, Langenberg JA, Beheler K, Batha CA, Dhuey BJ, Rolley RE, Bartelt G, Van Deelen TR, Samuel MD. 2003. Chronic wasting disease in free-ranging Wisconsin white-tailed deer. Emerg Infect Dis 9: 599-601.

Kataoka N, Nishimura M, Horiuchi M, Ishiguro N. 2005. Surveillance of chronic wasting disease in sika deer, Cervus nippon, from Tokachi district in Hokkaido. J Vet Med Sci 67: 349-351.

Keane DP, Barr DJ, Bochsler PN, Hall SM, Gidlewski T, O’Rourke KI, Spraker TR, Samuel MD. 2008. Chronic wasting disease in a Wisconsin white-tailed deer farm. $J$ Vet Diagn Invest 20: 698-703.

Khan MQ, Sweeting B, Mulligan VK, Arslan PE, Cashman NR, Pai EF, Chakrabartty A. 2010. Prion disease susceptibility is affected by $\beta$-structure folding propensity and local side-chain interactions in PrP. Proc Natl Acad Sci 107: 19808-19813.

Kim TY, Shon HJ, Joo YS, Mun UK, Kang KS, Lee YS. 2005. Additional cases of chronic wasting disease in imported deer in Korea. J Vet Med Sci 67: 753-759.

Klingenstein R, Löber S, Kujala P, Godsave S, Leliveld SR, Gmeiner P, Peters PJ, Korth C. 2006. Tricyclic antidepressants, quinacrine and a novel, synthetic chimera thereof clear prions by destabilizing detergent-resistant membrane compartments. J Neurochem 98: 748-759.

Klöhn PC, Stoltze L, Flechsig E, Enari M, Weissmann C. 2003. A quantitative, highly sensitive cell-based infectiv- 
J.A. Moreno and G.C. Telling

ity assay for mouse scrapie prions. Proc Natl Acad Sci 100: $11666-11671$

Kong Q, Huang S, Zou W, Vanegas D, Wang M, Wu D, Yuan J, Zheng M, Bai H, Deng H, et al. 2005. Chronic wasting disease of elk: Transmissibility to humans examined by transgenic mouse models. J Neurosci 25: 7944-7949.

Korth C, May BC, Cohen FE, Prusiner SB. 2001. Acridine and phenothiazine derivatives as pharmacotherapeutics for prion disease. Proc Natl Acad Sci 98: 9836-9841.

Kreeger TJ, Montgomery DL, Jewell JE, Schultz W, Williams ES. 2006. Oral transmission of chronic wasting disease in captive Shira's moose. J Wildl Dis 42: 640-645.

Kurt TD, Perrott MR, Wilusz CJ, Wilusz J, Supattapone S, Telling GC, Zabel MD, Hoover EA. 2007. Efficient in vitro amplification of chronic wasting disease $\operatorname{PrP}^{\mathrm{RES}}$. J Virol 81: 9605-9608.

Kurt TD, Telling GC, Zabel MD, Hoover EA. 2009. Transspecies amplification of $\mathrm{PrP}^{\mathrm{CWD}}$ and correlation with rigid loop 170N. Virology 387: 235-243.

Kurt TD, Bett C, Fernández-Borges N, Joshi-Barr S, Hornemann S, Rülicke T, Castilla J, Wüthrich K, Aguzzi A, Sigurdson CJ. 2014. Prion transmission prevented by modifying the $\beta 2-\alpha 2$ loop structure of host $\mathrm{PrP}^{\mathrm{C}}$. J Neurosci 34: 1022-1027.

Kurt TD, Jiang L, Fernández-Borges N, Bett C, Liu J, Yang T, Spraker TR, Castilla J, Eisenberg D, Kong Q, et al. 2015. Human prion protein sequence elements impede crossspecies chronic wasting disease transmission. J Clin Invest 125: 1485-1496.

LaFauci G, Carp RI, Meeker HC, Ye X, Kim JI, Natelli M, Cedeno M, Petersen RB, Kascsak R, Rubenstein R. 2006. Passage of chronic wasting disease prion into transgenic mice expressing Rocky Mountain elk (Cervus elaphus nelsoni) $\operatorname{PrP}^{\mathrm{C}}$. J Gen Virol 87: 3773-3780.

Lee YH, Sohn HJ, Kim MJ, Kim HJ, Park KJ, Lee WY, Yun EI, Tark DS, Choi YP, Cho IS, et al. 2013. Experimental chronic wasting disease in wild type VM mice. $J$ Vet Med Sci 75: 1107-1110.

Li J, Browning S, Mahal SP, Oelschlegel AM, Weissmann C. 2010. Darwinian evolution of prions in cell culture. Science 327: 869-872.

Liberski PP, Guiroy DC, Williams ES, Walis A, Budka H. 2001. Deposition patterns of disease-associated prion protein in captive mule deer brains with chronic wasting disease. Acta Neuropathol (Berl) 102: 496-500.

Marsh RF, Kincaid AE, Bessen RA, Bartz JC. 2005. Interspecies transmission of chronic wasting disease prions to squirrel monkeys (Saimiri sciureus). J Virol 79: $13794-$ 13796.

Martin S, Jeffrey M, González L, Sisó S, Reid HW, Steele P, Dagleish MP, Stack MJ, Chaplin MJ, Balachandran A. 2009. Immunohistochemical and biochemical characteristics of BSE and CWD in experimentally infected European red deer (Cervus elaphus elaphus). BMC Vet Res 5: 26.

Mathiason CK, Powers JG, Dahmes SJ, Osborn DA, Miller KV, Warren RJ, Mason GL, Hays SA, Hayes-Klug J, Seelig DM, et al. 2006. Infectious prions in the saliva and blood of deer with chronic wasting disease. Science 314: 133-136.
Mathiason CK, Nalls AV, Seelig DM, Kraft SL, Carnes K, Anderson KR, Hayes-Klug J, Hoover EA. 2013. Susceptibility of domestic cats to chronic wasting disease. J Virol 87: 1947-1956.

Mawhinney S, Pape WJ, Forster JE, Anderson CA, Bosque P, Miller MW. 2006. Human prion disease and relative risk associated with chronic wasting disease. Emerg Infect Dis 12: 1527-1535.

Mays CE, Joy S, Li L, Yu L, Genovesi S, West FG, Westaway D. 2012. Prion inhibition with multivalent $\operatorname{PrP}^{\mathrm{Sc}}$ binding compounds. Biomaterials 33: 6808-6822.

Meade-White K, Race B, Trifilo M, Bossers A, Favara C, Lacasse R, Miller M, Williams E, Oldstone M, Race R, et al. 2007. Resistance to chronic wasting disease in transgenic mice expressing a naturally occurring allelic variant of deer prion protein. J Virol 81: 4533-4539.

Meyerett C, Michel B, Pulford B, Spraker TR, Nichols TA, Johnson T, Kurt T, Hoover EA, Telling GC, Zabel MD. 2008. In vitro strain adaptation of CWD prions by serial protein misfolding cyclic amplification. Virology 382: 267-276.

Miller MW, Williams ES. 2003. Prion disease: Horizontal prion transmission in mule deer. Nature 425: 35-36.

Miller MW, Wild MA, Williams ES. 1998. Epidemiology of chronic wasting disease in captive Rocky Mountain elk. $J$ Wildl Dis 34: 532-538.

Miller MW, Williams ES, McCarty CW, Spraker TR, Kreeger TJ, Larsen CT, Thorne ET. 2000. Epizootiology of chronic wasting disease in free-ranging cervids in Colorado and Wyoming. J Wildl Dis 36: 676-690.

Miller MW, Williams ES, Hobbs NT, Wolfe LL. 2004. Environmental sources of prion transmission in mule deer. Emerg Infect Dis 10: 1003-1006.

Miller MW, Swanson HM, Wolfe LL, Quartarone FG, Huwer SL, Southwick CH, Lukacs PM. 2008. Lions and prions and deer demise. PLoS ONE 3: e4019.

Mitchell GB, Sigurdson CJ, O’Rourke KI, Algire J, Harrington NP, Walther I, Spraker TR, Balachandran A. 2012. Experimental oral transmission of chronic wasting disease to reindeer (Rangifer tarandus tarandus). PLoS ONE 7: e39055.

Nalls AV, McNulty E, Powers J, Seelig DM, Hoover C, Haley NJ, Hayes-Klug J, Anderson K, Stewart P, Goldmann W, Hoover EA, Mathiason CK. 2013. Mother to offspring transmission of chronic wasting disease in Reeves' muntjac deer. PLOS ONE 8: e71844.

Oklahoma Department of Wildlife Conservation. 2002. http://www.wildlifedepartment.com/facts_maps/archives/ 2002Whitetailarticles.htm.

O’Rourke KI, Besser TE, Miller MW, Cline TF, Spraker TR, Jenny AL, Wild MA, Zebarth GL, Williams ES. 1999. PrP genotypes of captive and free-ranging Rocky Mountain elk (Cervus elaphus nelsoni) with chronic wasting disease. J Gen Virol, 80: 2765-2769.

O’Rourke KI, Spraker TR, Hamburg LK, Besser TE, Brayton KA, Knowles DP. 2004. Polymorphisms in the prion precursor functional gene but not the pseudogene are associated with susceptibility to chronic wasting disease in white-tailed deer. J Gen Virol 85: 1339-1346.

O’Rourke KI, Spraker TR, Zhuang D, Greenlee JJ, Gidlewski TE, Hamir AN. 2007. Elk with a long incubation prion 
disease phenotype have a unique PrPd profile. Neuroreport 18: 1935-1938.

Pattison IH. 1965. Experiments with scrapie with special reference to the nature of the agent and the pathology of the disease. In Slow, Latent and Temperate Virus Infections, NINDB Monograph No. 2 (ed. Gajdusek DC, Gibbs CJ Jr, and Alpers MP), pp. 249-257. U.S. Government Printing, Washington, DC.

Peretz D, Scott MR, Groth D, Williamson RA, Burton DR, Cohen FE, Prusiner SB. 2001. Strain-specified relative conformational stability of the scrapie prion protein. Protein Sci 10: 854-863.

Pérez DR, Damberger FF, Wuthrich K. 2010. Horse prion protein NMR structure and comparisons with related variants of the mouse prion protein. $J$ Mol Biol 400: $121-128$.

Pritzkow S, Morales R, Moda F, Khan U, Telling GC, Hoover E, Soto C. 2015. Grass plants bind, retain, uptake, and transport infectious prions. Cell Rep 11: 1168-1175.

Prusiner SB, Scott M, Foster D, Pan KM, Groth D, Mirenda C, Torchia M, Yang SL, Serban D, Carlson GA, et al. 1990. Transgenetic studies implicate interactions between homologous PrP isoforms in scrapie prion replication. Cell 63: 673-686.

Pulford B, Spraker TR, Wyckoff AC, Meyerett C, Bender H, Ferguson A, Wyatt B, Lockwood K, Powers J, Telling GC, Wild MA, Zabel MD. 2012. Detection of PrPCWD in feces from naturally exposed Rocky Mountain elk (Cervus elaphus nelsoni) using protein misfolding cyclic amplification. J Wildl Dis 48: 425-434.

Race BL, Meade-White KD, Ward A, Jewell J, Miller MW, Williams ES, Chesebro B, Race RE. 2007. Levels of abnormal prion protein in deer and elk with chronic wasting disease. Emerg Infect Dis 13: 824-830.

Race B, Meade-White K, Race R, Chesebro B. 2009a. Prion infectivity in fat of deer with chronic wasting disease. $J$ Virol 83: 9608-9610.

Race B, Meade-White KD, Miller MW, Barbian KD, Rubenstein R, LaFauci G, Cervenakova L, Favara C, Gardner D, Long D, et al. 2009b. Susceptibilities of nonhuman primates to chronic wasting disease. Emerg Infect Dis 15: 1366-1376.

Race B, Meade-White K, Miller MW, Fox KA, Chesebro B. 2011. In vivo comparison of chronic wasting disease infectivity from deer with variation at prion protein residue 96. J Virol 85: 9235-9238.

Race B, Meade-White KD, Phillips K, Striebel J, Race R, Chesebro B. 2014. Chronic wasting disease agents in nonhuman primates. Emerg Infect Dis 20: 833-837.

Raymond GJ, Bossers A, Raymond LD, O'Rourke KI, McHolland LE, Bryant 3rd PK, Miller MW, Williams ES, Smits M, Caughey B. 2000. Evidence of a molecular barrier limiting susceptibility of humans, cattle and sheep to chronic wasting disease. EMBO J 19: 44254430.

Raymond GJ, Olsen EA, Lee KS, Raymond LD, Bryant 3rd PK, Baron GS, Caughey WS, Kocisko DA, McHolland LE, Favara C, et al. 2006. Inhibition of protease-resistant prion protein formation in a transformed deer cell line infected with chronic wasting disease. J Virol 80: 596604.
Raymond GJ, Raymond LD, Meade-White KD, Hughson AG, Favara C, Gardner D, Williams ES, Miller MW, Race RE, Caughey B. 2007. Transmission and adaptation of chronic wasting disease to hamsters and transgenic mice: evidence for strains. J Virol 81: 4305-4314.

Rhyan JC, Miller MW, Spraker TR, McCollum M, Nol P, Wolfe LL, Davis TR, Creekmore L, O’Rourke KI. 2011. Failure of fallow deer (Dama dama) to develop chronic wasting disease when exposed to a contaminated environment and infected mule deer (Odocoileus hemionus).J Wildl Dis 47: 739-744.

Roels S, Renard C, De Bosschere H, Geeroms R, Van Poucke M, Peelman L, Vanopdenbosch E. 2004. Detection of polymorphisms in the prion protein gene in the Belgian sheep population: some preliminary data. Vet Q 26: 311.

Ryou C, Prusiner SB, Legname G. 2003. Cooperative binding of dominant-negative prion protein to kringle domains. J Mol Biol 329: 323-333.

Sandberg MK, Al-Doujaily H, Sigurdson CJ, Glatzel M, O'Malley C, Powell C, Asante EA, Linehan JM, Brandner S, Wadsworth JD, Collinge J. 2010. Chronic wasting disease prions are not transmissible to transgenic mice overexpressing human prion protein. J Gen Virol 91: 26512657.

Saunders SE, Bartz JC, Vercauteren KC, Bartelt-Hunt SL. 2011. An enzymatic treatment of soil-bound prions effectively inhibits replication. Appl Environ Microbiol 77: 4313-4317.

Saunders SE, Bartelt-Hunt SL, Bartz JC. 2012. Occurrence, transmission, and zoonotic potential of chronic wasting disease. Emerg Infect Dis 18: 369-376.

Schätzl HM, Wopfner F, Gilch S, von Brunn A, Jäger G. 1997. Is codon 129 of prion protein polymorphic in human beings but not in animals? Lancet 349: 1603-1604.

Schettler E, Steinbach F, Eschenbacher-Kaps I, Gerst K, Muessdoerffer F, Risch K, Streich WJ, Frölich K. 2006. Surveillance for prion disease in cervids, Germany. Emerg Infect Dis 12: 319-322.

Scott M, Groth D, Foster D, Torchia M, Yang SL, DeArmond SJ, Prusiner SB. 1993. Propagation of prions with artificial properties in transgenic mice expressing chimeric PrP genes. Cell 73: 979-988.

Seelig DM, Nalls AV, Flasik M, Frank V, Eaton S, Mathiason CK, Hoover EA. 2015. Lesion profiling and subcellular prion localization of cervid chronic wasting disease in domestic cats. Vet Pathol 52: 107-119.

Seidel B, Thomzig A, Buschmann A, Groschup MH, Peters R, Beekes M, Terytze K. 2007. Scrapie agent (Strain 263K) can transmit disease via the oral route after persistence in soil over years. PLoS ONE 2: e435.

Sigurdson CJ, Williams ES, Miller MW, Spraker TR, O'Rourke KI, Hoover EA. 1999. Oral transmission and early lymphoid tropism of chronic wasting disease PrPres in mule deer fawns (Odocoileus hemionus). J Gen Virol 80: 2757-2764.

Sigurdson CJ, Spraker TR, Miller MW, Oesch B, Hoover EA. 2001. PrP ${ }^{C W D}$ in the myenteric plexus, vagosympathetic trunk and endocrine glands of deer with chronic wasting disease. J Gen Virol 82: 2327-2334.

Sigurdson CJ, Barillas-Mury C, Miller MW, Oesch B, van Keulen LJ, Langeveld JP, Hoover EA. 2002. PrP ${ }^{C W D}$ lym- 
J.A. Moreno and G.C. Telling

phoid cell targets in early and advanced chronic wasting disease of mule deer. J Gen Virol 83: 2617-2628.

Sigurdson CJ, Manco G, Schwarz P, Liberski P, Hoover EA, Hornemann S, Polymenidou M, Miller MW, Glatzel M, Aguzzi A. 2006. Strain fidelity of chronic wasting disease upon murine adaptation. J Virol 80: 12303-12311.

Sigurdson CJ, Mathiason CK, Perrott MR, Eliason GA, Spraker TR, Glatzel M, Manco G, Bartz JC, Miller MW, Hoover EA. 2008. Experimental chronic wasting disease (CWD) in the ferret. J Comp Pathol 138: 189-196.

Sigurdson CJ, Nilsson KP, Hornemann S, Heikenwalder M, Manco G, Schwarz P, Ott D, Rülicke T, Liberski PP, Julius C, et al. 2009. De novo generation of a transmissible spongiform encephalopathy by mouse transgenesis. Proc Natl Acad Sci 106: 304-309.

Sigurdson CJ, Nilsson KP, Hornemann S, Manco G, Fernández-Borges N, Schwarz P, Castilla J, Wüthrich K, Aguzzi A. 2010. A molecular switch controls interspecies prion disease transmission in mice. J Clin Invest 120: 2590 2599.

Smith CB, Booth CJ, Pedersen JA. 2011. Fate of prions in soil: A review. J Environ Qual 40: 449-461.

Sohn HJ, Kim JH, Choi KS, Nah JJ, Joo YS, Jean YH, Ahn SW, Kim OK, Kim DY, Balachandran A. 2002. A case of chronic wasting disease in an elk imported to Korea from Canada. J Vet Med Sci 64: 855-858.

Spraker TR, Miller MW, Williams ES, Getzy DM, Adrian WJ, Schoonveld GG, Spowart RA, O’Rourke KI, Miller JM, Merz PA. 1997. Spongiform encephalopathy in free-ranging mule deer (Odocoileus hemionus), white-tailed deer (Odocoileus virginianus), and Rocky Mountain elk (Cervus elaphus nelsoni) in northcentral Colorado. J Wildl Dis 33: 1-6.

Tamgüney G, Giles K, Bouzamondo-Bernstein E, Bosque PJ, Miller MW, Safar J, DeArmond SJ, Prusiner SB. 2006. Transmission of elk and deer prions to transgenic mice. $J$ Virol 80: 9104-9114.

Tamgüney G, Miller MW, Wolfe LL, Sirochman TM, Glidden DV, Palmer C, Lemus A, DeArmond SJ, Prusiner SB. 2009. Asymptomatic deer excrete infectious prions in faeces. Nature 461: 529-532.

Telling GC. 2011. Transgenic mouse models and prion strains. Top Curr Chem 305: 79-99.

Telling G. 2013. Chronic wasting disease and the development of research models. In Prions and diseases: Volume 2, Animals, humans and the environment (ed. Zou W-Q, Gambetti P), pp 45-57. Springer, New York.

Telling GC, Scott M, Mastrianni J, Gabizon R, Torchia M, Cohen FE, DeArmond SJ, Prusiner SB. 1995. Prion propagation in mice expressing human and chimeric $\operatorname{Pr} P$ transgenes implicates the interaction of cellular $\operatorname{PrP}$ with another protein. Cell 83: 79-90.

Telling GC, Parchi P, DeArmond SJ, Cortelli P, Montagna P, Gabizon R, Mastrianni J, Lugaresi E, Gambetti P, Prusiner SB. 1996. Evidence for the conformation of the pathologic isoform of the prion protein enciphering and propagating prion diversity. Science 274: 2079-2082.

U.S. Census Bureau. 2011. National Survey of Fishing, Hunting, and Wildlife-Associated Recreation (FHWAR). www .census.gov/prod/www/fishing.html.

Vickery CM, Lockey R, Holder TM, Thorne L, Beck KE, Wilson C, Denyer M, Sheehan J, Marsh S, Webb PR, et al. 2014. Assessing the susceptibility of transgenic mice overexpressing deer prion protein to bovine spongiform encephalopathy. J Virol 88: 1830-1833.

Vilette D, Andreoletti O, Archer F, Madelaine MF, Vilotte JL, Lehmann S, Laude H. 2001. Ex vivo propagation of infectious sheep scrapie agent in heterologous epithelial cells expressing ovine prion protein. Proc Natl Acad Sci 98: 4055-4059.

Wadsworth JD, Asante EA, Desbruslais M, Linehan JM, Joiner S, Gowland I, Welch J, Stone L, Lloyd SE, Hill AF, et al. 2004. Human prion protein with valine 129 prevents expression of variant CJD phenotype. Science 306: $1793-1796$.

Wasserberg G, Osnas EE, Rolley RE, Samuel MD. 2009. Host culling as an adaptive management tool for chronic wasting disease in white-tailed deer: A modelling study. J Appl Ecol 46: 457-466.

Williams ES. 2003. Scrapie and chronic wasting disease. Clin Lab Med 23: 139-159.

Williams ES. 2005. Chronic wasting disease. Vet Pathol 42: $530-549$.

Williams ES, Miller MW. 2002. Chronic wasting disease in deer and elk in North America. Rev Sci Tech 21: 305-316.

Williams ES, Young S. 1980. Chronic wasting disease of captive mule deer: A spongiform encephalopathy. J Wildl Dis 16: 89-98.

Williams ES, Young S. 1982. Spongiform encephalopathy of Rocky Mountain elk. J Wildl Dis 18: 465-471.

Williams ES, Young S. 1992. Spongiform encephalopathies in Cervidae. Rev Sci Tech Off Int Epiz 11: 551-567.

Williams ES, Young S. 1993. Neuropathology of chronic wasting disease of mule deer (Odocoileus hemionus) and elk (Cervus elaphus nelsoni). Vet Pathol 30: 36-45.

Wolfe LL, Fox KA, Miller MW. 2014. "Atypical” chronic wasting disease in PRNP genotype 225FF mule deer. $J$ Wildl Dis 50: 660-665. 


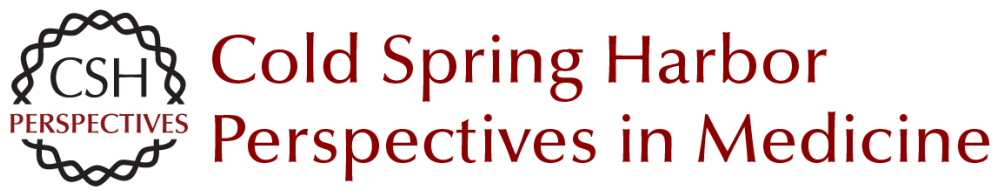

\section{Molecular Mechanisms of Chronic Wasting Disease Prion Propagation}

Julie A. Moreno and Glenn C. Telling

Cold Spring Harb Perspect Med 2018; doi: 10.1101/cshperspect.a024448 originally published online February 13, 2017

\section{Subject Collection Prion Diseases}

TDP-43 Prions

Takashi Nonaka and Masato Hasegawa

$\alpha$-Synuclein: Multiple System Atrophy Prions Amanda L. Woerman, Joel C. Watts, Atsushi Aoyagi, et al.

Genetics of Synucleinopathies Robert L. Nussbaum

$\beta$-Amyloid Prions and the Pathobiology of

Alzheimer's Disease Joel C. Watts and Stanley B. Prusiner

Disease Mechanisms of C9ORF72 Repeat Expansions

Tania F. Gendron and Leonard Petrucelli

Chronic Traumatic Encephalopathy: Is Latency in

Symptom Onset Explained by Tau Propagation? Joshua Kriegel, Zachary Papadopoulos and Ann C. McKee

Noncerebral Amyloidoses: Aspects on Seeding,

Cross-Seeding, and Transmission

Gunilla T. Westermark, Marcus Fändrich,

Katarzyna Lundmark, et al.

Structural and Chemical Biology of Presenilin

Complexes

Douglas S. Johnson, Yue-Ming Li, Martin

Pettersson, et al.
Cell Biology and Pathophysiology of $\alpha$-Synuclein Jacqueline Burré, Manu Sharma and Thomas C. Südhof

Molecular Mechanisms of Chronic Wasting

Disease Prion Propagation Julie A. Moreno and Glenn C. Telling

Genetics of Amyotrophic Lateral Sclerosis Mehdi Ghasemi and Robert H. Brown, Jr.

The Genetics of C9orf72 Expansions Ilse Gijselinck, Marc Cruts and Christine Van Broeckhoven

Prion-Like Characteristics of

Polyglutamine-Containing Proteins Margaret M.P. Pearce and Ron R. Kopito

Therapeutic Strategies for Restoring Tau Homeostasis

Zapporah T. Young, Sue Ann Mok and Jason E. Gestwicki

Fused in Sarcoma Neuropathology in Neurodegenerative Disease Ian R.A. Mackenzie and Manuela Neumann

Experimental Models of Inherited PrP Prion Diseases

Joel C. Watts and Stanley B. Prusiner

For additional articles in this collection, see http://perspectivesinmedicine.cshlp.org/cgi/collection/ 